\title{
STAKEHOLDER PRESSURE AND THE QUALITY OF SUSTAINABILITY REPORT: EVIDENCE FROM INDONESIA
}

\author{
Claudia Leonirda Lulu \\ Universitas Ciputra Surabaya
}

\begin{abstract}
This study aims to determine the effect of environmental pressure, consumer pressure, shareholder pressure, employee pressure, government pressure and creditor pressure on the quality of sustainability reports. The control variables of this study are profitability and company size. The sampling technique used is a purposive sampling method with the number of samples obtained as many as 69 non-financial sector companies listed in Indonesia Stock Exchange for the period of 2016-2018. A multiple linear regression method was used. The results of this study indicate that environmental pressure and consumer pressure have a positive effect on the quality of sustainability reports, while shareholder pressure, employee pressure, government pressure and creditor pressure do not affect the quality of sustainability reports. Profitability and company size as control variables in this study do not affect the quality of sustainability reports.
\end{abstract}

Keywords: stakeholder pressure, profitability, company size, quality of sustainability reports

\section{INTRODUCTION}

Corporate social responsibility (CSR) is a form of corporate social responsibility towards the community. Disclosure of corporate social responsibility is a process of communicating the social and environmental impacts of a company's economic activities on society (Darwinsyah, 2018). One of the communication media that companies use in disseminating information about social and environmental responsibility is the sustainability report.

A sustainability report is a practice of measuring and disclosing corporate responsibility activities such as organizational performance to stakeholders to

\footnotetext{
*Corresponding Author.

e-mail: claudialeonirda@gmail.com
} 
meet sustainability objectives (Alfaiz \& Aryati, 2019). The sustainability report allows companies to fulfil its obligations by communicating its performance in 3 aspects, namely economic, social, and environmental aspects. Disclosure of sustainability reports in Indonesia has increased from year to year. Until the end of 2016, there were 120 companies that published sustainability reports in Indonesia (Putri, 2016). However, the increase in disclosure on the sustainability report is not proportional to the quality of disclosure. This is found in the results of research in Figure 1 conducted by the Center for Governance, Institutions, and Organizations of the National University of Singapore (NUS) Business School which shows that disclosure of sustainability in Indonesia has increased from 48,4 to 53,6 in 2017. Indonesia has experienced a decline in position in which 2015 occupies the third position, while 2017 occupies the last position. This indicates that the quality of sustainability disclosure in Indonesia is relatively low compared to Malaysia, Singapore, and Thailand.

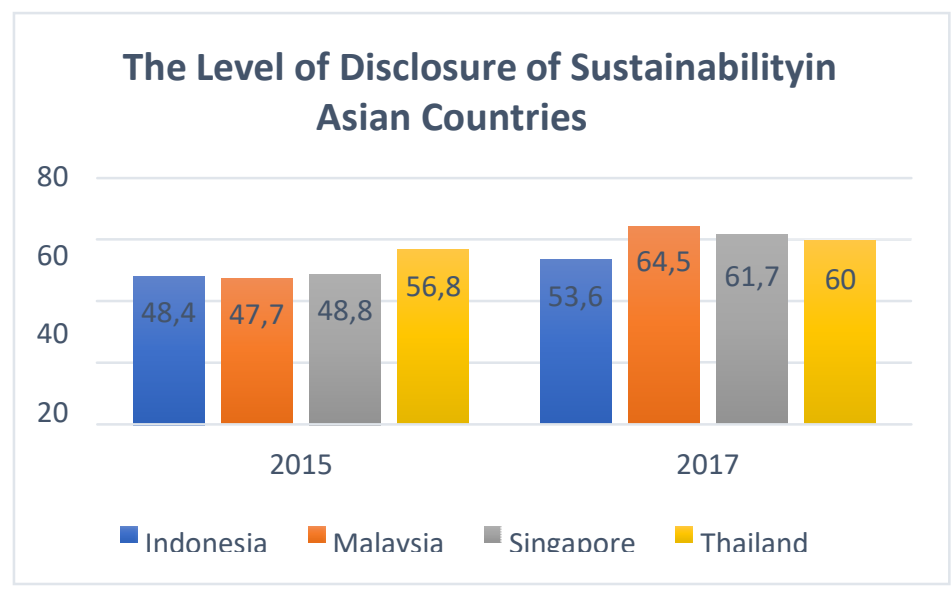

Figure 1 The Level of Disclosure of Sustainability in Asian Countries Source. Center for Governance, Institutions, and Organizations (2019)

The quality of information is essential to assist stakeholders in providing valid and reasonable assessments of the organization and to take appropriate action (globalreporting.org). Therefore, stakeholders can encourage companies to publish sustainability reports. This is in line with the statement from Hamudiana \& Achmad (2017) that several factors including stakeholder pressure can cause 
companies to issue sustainability report. Pressure from stakeholders requires a company to carry out and deliver CSR activities in the form of quality reports (Alfaiz \& Aryati, 2019).

A person, group, or organization that has an interest in a particular organization is called a stakeholder. Each industry groups can receive different stakeholder pressure. According to Feijo et al. (2012, in Suharyani et al., 2019), primary stakeholders are consumers, investors, employees, and the environment. Meanwhile, according to Vitolla et al. (2019) and Ramadhini et al. (2020) secondary stakeholders refer to the government and creditors.

This study aims to determine the effect of environmental pressure, consumer pressure, shareholder pressure, employee pressure, government pressure, and creditor pressure on the quality of sustainability reports on non-financial sector companies listed on Indonesia Stock Exchange for the period of 2016-2018.

The reason researchers did not choose the financial sector was due to the different policies applied and its stringent regulation. There are 6 hypotheses formulated in this study, which are as follows:

H1: Environmental pressure positively influences the quality of sustainability reports.

H2: Consumer pressure has a positive effect on the quality of sustainability reports.

H3: Shareholder pressure has a positive effect on the quality of sustainability reports.

H4: Employee pressure has a positive effect on the quality of sustainability reports.

H5: Government pressure has a positive effect on the quality of sustainability reports.

H6: Creditors' pressure has a positive effect on the quality of sustainability reports.

\section{METHOD}

The type of data in this study is pooling data. Pooling data is a combination of time-series data (between times) and cross-section data (between individuals/ spaces) (Ghozali, 2018). Sources of data in this study uses secondary data 
obtained from annual reports of companies listed on IDX that published sustainability reports in 2016-2018. The measurement scales used in this study are nominal and ratio scales.

\section{Population and Sample}

The population used in this study are all non-financial sector companies listed on Indonesia Stock Exchange (BEI) in 2016-2018. The sampling technique in this study is a non-probability sampling type of purposive sampling. The sampling criteria are as follows:

1. All non-financial sector companies listed on the Indonesia Stock Exchange in 2016-2018.

2. Companies that publish annual reports in 2016-2018.

3. Companies that publish sustainability reports separately from annual reports through IDX or the official website of each respective companies in 20162018.

4. Companies that issue sustainability reports using GRI-Standard 2016.

\section{Operational Definition and Variable Measurement}

1. Quality of Sustainability Reports

Measurement of the quality of sustainability report refers to measurements from Suharyani et al. (2019) using content analysis based on GRI-Standard 2016. The weight given is based on the completeness of the reports disclosed.

Weight $0=$ not revealed

Weight 1 = express and provide a qualitative explanation

Weight 2 = express and provide a qualitative explanation and provide data with nominal (quantitative) numbers for each indicator disclosed.

The total weight that has been given to each item analyzed is then calculated using the formula:

$$
\text { DISCGRI }=\frac{\text { Number of scores revealed }}{\text { The maximum number of scores expected }}
$$




\section{Environmental Pressure}

The source of power from the environment comes in the form of group concerns (Luo et al., 2017). These groups demand companies to regenerate the Earth that has been damaged by companies in meeting operational needs (Rudyanto \& Siregar, 2018). Environmental pressure is measured using dummy variables by classifying companies included in industries with the potential to cause high environmental impacts (Alfaiz \& Aryati, 2019). Companies with high environmental impacts tend to disclose more transparent social and environmental responsibility information. This occur because the company will be subject to greater pressure on environmental issues than other companies (Yuliskayani \& Damayanthi, 2018). In addition, this also relates to the theory of legitimacy because companies from environmentally sensitive industries tend to disclose quality sustainability reports to gain legitimacy from the public regarding the company operations.

Companies included in the industry are those that have an impact on the agricultural, chemical, mining, construction, machinery, motor vehicle parts and components, cables, property, housing, energy, highways, airways, ports, nonbuilding construction, and electronics industries. If a company is included in the above industry, then a score of 1 is given while other industries are given a value of 0 .

\section{Consumer Pressure}

Companies with high closeness to consumers tend to be more distinctive and is most likely to influence other companies to conduct their social and environmental responsibilities. Companies tend to build a good image in front of consumers and will not only produce products according to the desires and needs of consumers, but will rather try to show their responsibilities outside of its main activities, namely seeking profit (Hamudiana \& Achmad, 2017).

Consumer pressure is measured by classifying industries that are close to consumers (Rudyanto \& Siregar, 2018). The industry consists of the consumer goods industry, financial services, restaurants, hotels and tourism, retail goods, printing, advertising, media, health care, textiles and garments, footwear, energy, investment, and the telecommunications industry. Companies included in the 
industries listed above are given a value of 1 , while those not included are given a value of 0 .

\section{Shareholder Pressure}

Shareholder pressure is measured by the concentration of ownership structure (Thomsen et al., 2006 in Rudyanto \& Siregar, 2018). The concentration of ownership is a condition where most of the company's shares are owned by a small number of individuals or groups, thus making these shareholders procure more dominant shares than other shareholders (Susanto \& Joshua, 2018). The dominant shareholder has control over the company in such a way that all actions are a reflection of the owner's will. Besides, the supervisory process of shareholders of the company's management needs to run well so that the act of withholding information will be reduced and encourage companies to conduct wider disclosures.

$$
\text { Level of concentration }=\underline{\text { Number of shares of parent company }}
$$

\section{Total number of shares}

\section{Employee Pressure}

Employees are one of the stakeholders that have strong potential in pressuring companies to express social and environmental responsibility (Friske et al., 2019). This happens because the higher the CSR disclosure, the greater the employee commitment and satisfaction as well as other benefits such as educational support or improvement of occupational health and safety.

$$
\text { Employee pressure }=\text { Ln (Number of Employees) }
$$

\section{Government Pressure}

Regulations issued by the government are important aspects that companies need to pay attention to. The issued regulations includes company operational permits, regulations regarding labor, and others (Ilene, 2017). State-owned companies or BUMN indirectly belong to the whole community. That said, they receive more attention and demands from the public over the disclosure of information which makes the government pressure on company management to publish sustainability reports to avoid public's demand for information disclo- 
sure. Government pressure is measured by differentiating between BUMN and private companies (Pratiwi, 2017). A value of 1 for state-owned companies and a value of 0 for private companies.

\section{Creditor Pressure}

Creditors are parties that provide funds for companies to run their businesses (Ramadhini et al., 2020). Companies with high financial risk tend to disclose more information because social and environmental aspects can be included as one of the assessment criteria in considering the funds that will be given to the company. Creditors' pressure can be measured using a debt ratio by comparing total equity (Weihena et al., 2017).

$$
\mathrm{DER}=\frac{\text { Total liability }}{\text { Total equity }}
$$

8. Profitability

Profitability in this study is a control variable. Profitability is a ratio that shows the company's ability to generate profits (Azzaki, 2019).

$$
\mathrm{ROA}=\frac{\text { Net profit }}{\text { Total asset }}
$$

9. Company Size

Company size is a control variable in this study. Company size can be determined by the number of employees, total assets, and total sales. The indicator in measuring the firm size is referring to the measurement (Rudyanto \& Siregar, 2018).

$$
\text { Firm size }=\text { Ln (total asset) }
$$

\section{RESULTS}

The objects examined in this study are non-financial sector companies listed on Indonesia Stock Exchange in the 2016-2018 period. The total sample obtained in this study were 42 companies with 69 observations. The list of research samples is in Table 1 . 
Journal of Accounting, Entrepreneurship, and Financial Technology

Volume 02, Number 01, October 2021

Table 1 Sample Data

\begin{tabular}{|c|c|c|c|c|}
\hline \multirow{2}{*}{ No. } & \multirow{2}{*}{ Company Name } & \multicolumn{3}{|c|}{ Year } \\
\hline & & 2016 & 2017 & 2018 \\
\hline 1 & ABM Investama & & & \\
\hline 2 & AKR Corporindo Tbk, PT & & & \\
\hline 3 & Aneka Tambang (Persero) Tbk & & & \\
\hline 4 & Astra International Tbk & & & \\
\hline 5 & Astra Otoparts Tbk & & & \\
\hline 6 & Austindo Nusantara Jaya Tbk & & & \\
\hline 7 & Bukit Asam (Persero) Tbk & & & \\
\hline 8 & Bumi Resources Tbk & & & \\
\hline 9 & Bumi Serpong Damai Tbk & & & \\
\hline 10 & Chandra Asri Petrochemical Tbk & & & \\
\hline 11 & Eagle High Plantations Tbk & & & \\
\hline 12 & Garuda Indonesia (Persero) Tbk & & & \\
\hline 13 & Garuda Maintenance Facility Aero Asia Tbk & & & \\
\hline 14 & Indah Kiat Pulp \& paper Tbk & & & \\
\hline 15 & Indo Tambang Raya Megah Tbk & & & \\
\hline 16 & Indocement Tunggal Prakarsa Tbk & & & \\
\hline 17 & Japfa Comfeed Indonesia Tbk & & & \\
\hline 18 & Jasa Marga (Persero) Tbk & & & \\
\hline 19 & Kalbe Farma Tbk & & & \\
\hline 20 & Lotte Chemical Titan Tbk & & & \\
\hline 21 & Medco Energi International Tbk & & & \\
\hline 22 & Merck Tbk & & & \\
\hline 23 & Multi Bintang Indonesia Tbk & & & \\
\hline 24 & Pembangunan Jaya Ancol Tbk & & & \\
\hline 25 & Pembangunan Perumahan (Persero) Tbk & & & \\
\hline 26 & Perusahaan Gas Negara (Persero) Tbk & & & \\
\hline 27 & Petrosea Tbk & & & \\
\hline 28 & Phapros Tbk & & & \\
\hline 29 & PP London Sumatera Indonesia Tbk & & & \\
\hline 30 & Salim Ivomas Pratama Tbk & & & \\
\hline 31 & Sawit Sumbermas Sarana Tbk & & & \\
\hline 32 & Semen Indonesia (Persero) Tbk & & & \\
\hline 33 & SMART Tbk & & & \\
\hline 34 & Solusi Bangun Indonesia Tbk & & & \\
\hline 35 & Total Bangun Persada Tbk & & & \\
\hline 36 & Unilever Indonesia Tbk & & & \\
\hline 37 & Vale Indonesia Tbk (Inco Indonesia Tbk) & & & \\
\hline 38 & Waskita Beton Precast Tbk & & & \\
\hline 39 & Waskita Karya (Persero) Tbk & & & \\
\hline 40 & Wijaya Karya (Persero) Tbk & & & \\
\hline 41 & Wijaya Karya Beton Tbk & & & \\
\hline 42 & XL Axiata Tbk & & & \\
\hline
\end{tabular}




\section{Descriptive Statistics}

Table 2 shows that the environmental pressure variable consisting of variables with a dummy value of 47 is 47 with a percentage of $68.1 \%$ of companies in environmentally sensitive industries, while the rest are not environmentally sensitive.

Table 2 Descriptive Statistic Environmental Pressure

\begin{tabular}{lccccc}
\hline \multicolumn{5}{c}{ Environmental Pressure } \\
\hline & Frequency & Percent & $\begin{array}{c}\text { Valid } \\
\text { Percent }\end{array}$ & $\begin{array}{c}\text { Cumulative } \\
\text { Percent }\end{array}$ \\
\hline Valid & 0 & 22 & 31.9 & 31.9 & 31.9 \\
& 1 & 47 & 68.1 & 68.1 & 100.0 \\
& Total & 69 & 100.0 & 100.0 & \\
\hline
\end{tabular}

Table 3 shows that the consumer pressure variable which consists of variables with a dummy value of 1 totaling 12 with a percentage of $17.4 \%$ are companies included in the industry that are close to consumers, and as many as 57 with a percentage of $82.6 \%$ are companies that are not close to consumers.

Table 3 Descriptive Statistic Consumer Pressure

\begin{tabular}{lccccc}
\hline & & Frequency & Percent & $\begin{array}{c}\text { Valid } \\
\text { Percent }\end{array}$ & $\begin{array}{c}\text { Cumulative } \\
\text { Percent }\end{array}$ \\
\hline Valid & 0 & 57 & 82.6 & 82.6 & 82.6 \\
& 1 & 12 & 17.4 & 17.4 & 100.0 \\
& Total & 69 & 100.0 & 100.0 & \\
\hline
\end{tabular}

Table 4 shows that the government pressure variable consisting of variables with a dummy 1 value of 20 with a percentage of $29 \%$ is a BUMN company, while 49 with a percentage of $71 \%$ is a private company.

Table 4 Descriptive Statistic Government Pressure

\begin{tabular}{cccccc}
\hline \multicolumn{5}{c}{ Government Pressure } \\
\hline Valid & 0 & 49 & 71.0 & 71.0 & 71.0 \\
& 1 & 20 & 29.0 & 29.0 & 100.0 \\
& Total & 69 & 100.0 & 100.0 & \\
\hline
\end{tabular}


Table 5 shows that the minimum value of the shareholder pressure variable is 0.10186 and the maximum value is 0.97204 , while the mean value of the stockholder pressure variable is 0.5931196 and the standard deviation value is 0.18550520 . The minimum value of the employee pressure variable is 4.20469 and the maximum value is 12.32891 , while the mean and standard deviation are 8.4167089 and 1.42942418. Creditors' pressure gained a minimum value of 0.13657 and a maximum value of 6.75751 , while an average value of 1.4715875 and a standard deviation of 1.21252165. The minimum and maximum values of the profitability control variable are -0.05722 and 0.92100 , while the mean and standard deviation values are 0.0715859 and 0.12936240 . The size of the company as a control variable gets the minimum and maximum values of 27.50692 and 33.447373, while the average value is 30.8000497 and the standard deviation is 1.22085507 . The minimum value of the sustainability report quality variable measured using the 2016 GRI-Standards is 0.11688 by PT Lotte Chemical Titan Tbk in 2017, while the maximum value of 0.87013 in 2017 is owned by PT Indah Kiat Pulp \& Paper Tbk. The mean (average) value is 0.4724261 and the standard deviation is 0.18023018 .

Table 5 Descriptive Statistic

\begin{tabular}{lrrrrr}
\hline & $\mathbf{N}$ & \multicolumn{1}{c}{ Minimum } & \multicolumn{1}{c}{ Maximum } & \multicolumn{1}{c}{ Mean } & \multicolumn{1}{l}{ Std. Deviation } \\
\hline TPS & 69 & .10186 & .97204 & .5931196 & .18550520 \\
\hline TKAR & 69 & 4.20469 & 12.32891 & 8.4167089 & 1.42942418 \\
\hline TKR & 69 & .13657 & 6.75751 & 1.4715875 & 1.21252165 \\
\hline ROA & 69 & -.05722 & .92100 & .0715859 & .12936240 \\
\hline SZ & 69 & 27.50692 & 33.47373 & 30.8000497 & 1.22085507 \\
\hline KSR & 69 & .11688 & .87013 & .4724261 & .18023018 \\
\hline Valid N & 69 & & & & \\
\hline (listwise) & & & & & \\
\hline
\end{tabular}

\section{Classic Assumption Test}

The results of the classic assumption test consisting of a normality test, autocorrelation test, and heteroscedasticity test in this study have passed the test 
with a significant value above 0.05 . Meanwhile, the multicollinearity test also passed the test with a tolerance value $\geq 0.10$ or VIF $\leq 10$.

Table 6 Normality Test using Kolmogorov-Sminorv

\begin{tabular}{cccc}
\hline & $\begin{array}{c}\text { Unstandardized } \\
\text { Residual }\end{array}$ & $\begin{array}{c}\text { Criteria for Normal } \\
\text { Distributed Data }\end{array}$ & Result \\
\hline Asymp Sig. (2-tailed) & 0,200 & Sig $>0,05$ & Normal \\
\hline
\end{tabular}

Table 7 Multicollinearity Test using Tolerance Value and VIF

\begin{tabular}{lccl}
\hline Variable & Tolerance & VIF & Result \\
\hline TL & 0,493 & 2,028 & There is no multicollinearity \\
TKN & 0,434 & 2,306 & There is no multicollinearity \\
TPS & 0,857 & 1,167 & There is no multicollinearity \\
TKAR & 0,620 & 1,613 & There is no multicollinearity \\
TPM & 0,633 & 1,581 & There is no multicollinearity \\
TKR & 0,778 & 1,285 & There is no multicollinearity \\
ROA & 0,735 & 1,360 & There is no multicollinearity \\
SZ & 0,445 & 2,247 & There is no multicollinearity \\
\hline
\end{tabular}

Table 8 Autocorrelation Test Using Run Test

\begin{tabular}{ccc}
\hline Asymp. Sig. & 0,545 & There is no autocorrelation \\
\hline
\end{tabular}

Table 9 Heteroscedasticities Test Using Glejser Test

\begin{tabular}{ccc}
\hline Variable & Sig. & Result \\
\hline TL & 0,652 & There is no heteroscedasticities \\
TKN & 0,595 & There is no heteroscedasticities \\
TPS & 0,534 & There is no heteroscedasticities \\
TKAR & 0,662 & There is no heteroscedasticities \\
TPM & 0,189 & There is no heteroscedasticities \\
TKR & 0,546 & There is no heteroscedasticities \\
ROA & 0,399 & There is no heteroscedasticities \\
SZ & 0,072 & There is no heteroscedasticities \\
\hline
\end{tabular}

\section{Multiple Linear Regression Method}

Based on Table 10, the regression models that can be made are as follows:

$$
\begin{aligned}
\mathrm{KSR}= & -0.255+0.384 \mathrm{TL}+0.380 \mathrm{TKN}+0.157 \mathrm{TPS}-0.017 \mathrm{TKAR}-0.023 \mathrm{TPM} \\
& -0.005 \mathrm{TKR}
\end{aligned}
$$


Table 10 Multiple Linear Regression

\begin{tabular}{lc}
\hline \multicolumn{1}{c}{ Model } & Unstandardized Coefficients \\
\hline (Constant) & $-0,255$ \\
TL & 0,384 \\
TKN & 0,380 \\
TPS & 0,157 \\
TKAR & $-0,017$ \\
TPM & $-0,023$ \\
TKR & $-0,005$ \\
ROA & 0,005 \\
SZ & 0,016 \\
\hline
\end{tabular}

\section{Goodness of Fit Test}

Based on Table 11, the $\mathrm{F}$ test results that shows the significant value generated in the $\mathrm{F}$ test is $0.008<0.05$. Hence it can be concluded that the regression model in this study is appropriate or feasible. The adjusted R2 test results in Table 12 shows that the adjusted R2 values in Table 13 are 0.186 or $18.6 \%$. Thus, it can be concluded that the ability of stakeholder pressure variables in explaining the quality of the sustainability report $(\mathrm{Y})$ is $18.6 \%$ while the remaining $81.4 \%$ is explained by other factors.

Table 11 Result of F-Statistic test

\begin{tabular}{ccc}
\hline & F & Significant \\
\hline Regression & 2,947 & 0,008 \\
\hline
\end{tabular}

Table 12 Result of Determination Coefficient (Adjusted R2)

\begin{tabular}{cc}
\hline $\mathbf{R}^{2}$ & Adjusted $^{2}$ \\
\hline 0,282 & 0,186 \\
\hline
\end{tabular}

\section{Hypothesis Test}

Table 13 is the result of the t-test, which shows that environmental pressure has a regression coefficient of 0.384 and a significance value of $0.000<0.05$. These results indicate that environmental pressure have a positive effect on the 
quality of sustainability reports. Consumer pressure have a regression coefficient of 0.380 and a significance value of $0.001<0.05$. These results indicate that consumer pressure has a positive effect on the quality of sustainability reports, while shareholder pressure, employee pressure, government pressure, creditor pressure, and control variables namely profitability and company size do not affect the quality of the sustainability report because it has a significance value $>0.05$.

Table 13 Result of t-test

\begin{tabular}{lcc}
\hline \multicolumn{1}{c}{ Model } & Koefisien Regresi & Sig. \\
\hline (Konstanta) & $-0,255$ & 0,706 \\
TL & 0,384 & 0,000 \\
TKN & 0,380 & 0,001 \\
TPS & 0,157 & 0,176 \\
TKAR & $-0,017$ & 0,330 \\
TPM & $-0,023$ & 0,672 \\
TKR & $-0,005$ & 0,799 \\
ROA & 0,005 & 0,976 \\
SZ & 0,016 & 0,514 \\
\hline
\end{tabular}

\section{DISCUSSION}

\section{Relationship of Environmental Pressure on the Quality of Sustainability Reports}

The results of this study indicate that companies included in environmentally sensitive industries have a positive effect on the quality of sustainability reports as they tend to express quality, social and environmental responsibility. Companies with the potential for a large impact of environmental damage is more subject to greater pressure on environmental problems than other companies. Transparent implementation and disclosure of social and environmental responsibility shows the company's efforts to meet the demands of environmental organizations or groups (Alfaiz \& Aryati, 2019).

Besides, the results of this study also indicate that Indonesian people have a concern for the environment and the company's operational impact on the environment. This concern arises because of the issue of natural damage which made the community aware of the importance of managing existing natural 
resources. Therefore, it is important for companies to use and manage the limited natural resources as efficiently as possible in meeting the operational needs. To reduce the risks and accusations addressed to the company and create a mutually harmonious relationship between the company, the community and its environment, the company will carry out social and environmental responsibility activities and disclose them in the sustainability report.

Stakeholder theory explains that companies are not only responsible to shareholders as investors but are also responsible to other parties, both directly and indirectly (Susanto \& Joshua, 2018). The results of this study are in line with stakeholder theory because these results indicate that companies included in environmentally sensitive industries publish quality sustainability reports as a form of corporate responsibility to meet the stakeholder expectations, in this case organizations or environmental groups using the information available in sustainability reports that can assist them in assessing the extent of the company's contribution to sustainable development. Furthermore, the results of this study also support the theory of legitimacy in which companies with the potential of environmental damage will disclose higher quality environmental performance to reduce pressure from communities and groups concerned about the environment and to legitimize its operations, or in other words so that company activities can be accepted by the environment and society.

\section{Relationship of Consumer Pressure on the Quality of Sustainability Reports}

The results show that consumer pressure has a positive effect on the quality of sustainability reports where the results of this study support the outcome of research conducted by Rudyanto \& Siregar (2018) and Alfaiz \& Aryati (2019).

These results indicate that consumers are very concerned about the goods and services they use. In consuming goods or services from a company, consumers not only spend their money to buy affordable goods or services, but also tend to pay attention to whether the product is made from environmentally friendly materials, there are no forced labor, and other sustainability considerations. Companies that have close relationships with consumers have social visibility and will tend to consider important issues of community involvement in social responsibility activities carried out by the company and disclose this information 
into sustainability reports while the company seeks to obtain an accountable brand reputation from the community to help boost and influence sales.

The results of this study are in line with stakeholder theory given that company management can meet stakeholder (consumer) expectations by carrying out social and environmental responsibility as disclosed in quality sustainability reports to assist consumers in making decisions. According to Yuliskayani \& Damayanthi (2018), the more crucial the stakeholders are to the company, the greater the company's efforts in managing the close relationship of an industry with consumers.

\section{Relationship of Shareholder Pressure on the Quality of Sustainability Reports}

The results showed that shareholder pressure did not affect the quality of sustainability reports. This is caused by the holding company as the controlling shareholder not utilizing its rights to monitor and control the performance of the company's management in attempting to maintain the company's sustainability. Typically, to determine which companies are invested, shareholders tend to pay less attention to which corporate social responsibility is better. For shareholders, the most important aspect of investing is to get profits through dividends. Thus, the existence of a sustainability report makes shareholders worry as it can lead to additional costs that can reduce the return on investment. This results in the controlling shareholders asking management not to carry out and disclose corporate social responsibility to meet shareholders' objectives in obtaining maximum profit. Also, because the disclosure of sustainability reports in Indonesia is still voluntary, the shareholders do not force the company to disclose it.

Stakeholder theory states that stakeholders can influence company actions (Suharyani et al., 2019). Pressure from stakeholders can encourage companies to implement and disclose sustainability reports. Thus, it can be concluded that the results of this study are not in line with stakeholder theory as shareholder pressure is not proven to influence the company to disclose sustainability reports. This also indicates that the company is unable to meet stakeholder expectations to provide quality information on its activities, in this case information relating to the company's responsibility towards the economic, social, and environmental. 


\section{Relationship of Employee Pressure on the Quality of Sustainability Reports}

The results showed that employee pressure did not affect the quality of sustainability reports. These results are in line with the results of research conducted by Rudyanto \& Siregar (2018) which states that employee pressure does not affect the quality of sustainability reports. This is because most employees in Indonesia view the social and environmental responsibilities disclosed in the sustainability report as something that can harm the company and reduce the company's value. Employees see that social and environmental responsibility carried out by the company can add to the burden of the company and can result on reducing salaries. Moreover, the social and environmental responsibility practices reported in the sustainability report are not well socialized to employees, which makes employees feel excluded.

The results of this study are not in line with stakeholder theory because employee pressure is proven not to influence the company to disclose sustainability reports, contrary to the stakeholder theory explanation which states that the presence of stakeholders can always influence company actions. This also indicates that the company cannot meet stakeholder expectations to provide quality information about the company's activities, in this case information relating to the company's responsibility towards the economic, social, and environmental.

\section{Relationship of Government Pressure on the Quality of Sustainability Reports}

The results showed that government pressure did not affect the quality of sustainability reports. This happens because there are legal issues in several laws, government regulations or ministerial regulations relating to corporate social responsibility which then become a loophole for companies to not implement and disclose these regulations, or implement and disclose but not implemented as they should.

One of the legal issues in some regulations is that the sanctions listed in the regulations are unclear. For example, Article 74 paragraph (3) of Law No.40 of 2007 on Limited Liability Companies which states that if a company does not carry out its obligations, it will be subject to sanctions by applicable laws and regulations. This statement provides the view that there is no legal certainty as 
it is not clearly explained what laws and sanctions will be imposed on companies that do not carry out CSR. Strict and clear sanctions are urgently needed in regulations regarding social and environmental responsibility because they are closely related to the welfare of the community, which makes the need for a strong and compliant force.

Also, there are weaknesses in regulations issued by the government where it only regulates the implementation and disclosure of corporate social responsibility but do not provide specific guidelines that explains what items should be reported and how to report them. This makes CSR disclosures in companies in Indonesia different because there are no specific standards governing the disclosure of social and environmental responsibility.

Stakeholder theory explains that in order to meet the demands of stakeholders and ensure the existence of a company obtained from the support of stakeholders, the company needs to adjust its strategy (Julia \& Erwin, 2017). One of the company's strategies is to provide more complete information related to activities and its impact on social and environmental conditions in the form of sustainability reports. The results of this study are not based on stakeholder theory as the company is unable to provide information on its activities, in this case information relating to corporate responsibility towards economic, social and environmental.

\section{Relationship of Creditor Pressure on the Quality of Sustainability Reports}

The results of this study indicate that creditor pressure does not affect the quality of the sustainability report. This happens because creditors do not care about the amount of information disclosed by the company regarding CSR in providing funds to the company. For creditors, the most important thing is that the debt borrowed by the company can be returned according to the specified deadline. Creditors and companies have private access to communicate with each other. Thus, the level of leverage ratios used to measure creditor pressure does not affect the quality of the sustainability report.

The results of this study are not in line with stakeholder theory as creditor pressure is proven to be non-influential for companies to disclose sustainability reports. This also indicates that the company is unable to meet the stakeholder 
expectations to provide information about the company's activities, in this case information relating to the company's responsibilities to the economy, social and environment.

\section{Conclusion}

Based on the results of research, it can be concluded that environmental pressure and consumer pressure have a positive effect on the quality of sustainability reports. Meanwhile, shareholder pressure, employee pressure, government pressure, and creditor pressure did not affect the quality of sustainability reports.

\section{Limitations and Suggestions}

This study still has limitations, namely this study was conducted in 20162018. During this period, there was an adjustment from G4 to GRI Standard, in which the GRI Standard also experienced the addition of items in 2018. As a result, many non-financial sector companies were still using G4 standards while some are already using GRI-Standard 2018 and 2019.

Suggestion for future research is to use the GRI-Standard 2018 guidelines or use guidelines other than GRI. In addition, further research should use or add other variables related to the quality of sustainability reports such as corporate governance, financial performance, and company characteristics.

\section{REFERENCES}

Alfaiz, D. R. \& Aryati, T. (2019). Pengaruh Tekanan Stakeholder dan Kinerja Keuangan Terhadap Kualitas Sustainability Report dengan Komite Audit sebagai Variabel Moderasi. Jurnal Akuntansi dan Keuangan Methodist, 2(2), 112-130.

Azzaki, M. R. (2019). Corporate Social Responsibility dalam Memoderasi Pengaruh Karakteristik Perusahaan dan Corporate Governance terhadap Sustainability Report. Jurnal Ilmiah Akuntansi dan Humanika, 9(2), 114-124. 
Center for Governance, Institutions, and Organizations of the National University of Singapore. (2019). The Level of Disclosure of Sustainability in Asian Countries. National University of Singapore (NUS) Business School.

Darwinsyah, M. (2018). Analisis Pengaruh Strategi Komunikasi CSR melalui media sosial Terhadap Reputasi Perusahaan (Studi Kasus pada Perusahaan Consumer Goods di Indonesia. Jurnal Komunikasi, 3(1), 59-72.

Feijoo, B. F. \& Romeo, S. (2014). Effect of Stakeholders' Pressure on Transparency of Sustainability Reports within the GRI Framework. Journal Business Ethics, 53-63.

Friske, W., Nikolov, A.N., \& Hoang, P. (2019). CSR Reporting Practices : An Integrative Model and Analysis. Journal of Marketing Theory and Practice, $1-18$.

Ghozali, I. (2018). Aplikasi Analisis Multivariete SPSS 25 (9th ed.). Semarang: Universitas Diponegoro.

Hamudiana, A. \& Achmad, T. (2017). Pengaruh Tekanan Stakeholder Terhadap Transparansi Laporan Keberlanjutan Perusahaan-Perusahaan di Indonesia. Diponegoro Journal of Accounting, 6(4), 1-11.

Ilene. (2016). Pengaruh Tipe Industri, Ukuran Perusahaan, Kepemilikan Asing, Regulasi Pemerintah, Metode dan Gaya Komunikasi, Performance Tata Kelola Perusahaan Terhadap Luas Pengungkapan Corporate Social Responsibility. Media Riset Akuntansi, 6(2), 61-86.

Julia. \& Erwin. (2017). Analisis Pengaruh Kepemilikan Saham Terkonsentrasi, Pemerintah dan Asing, Terhadap Pengungkapan Tanggung Jawab Sosial Perusahaan (Studi Empiris pada Perbankan Indonesia yang terdaftar di BEI Tahun 2013-2015). Jurnal Ekonomi dan Manajemen STIE Pertiba Pangkalpinang, 1(1), 75-88.

Luo, J.M., Lam, C.F., Chau, K.Y., Shen, H.W., \& Wang, X. (2017). Measuring Corporate Social Responsibility in Gambling Industry: Multi-Items Stakeholder Based Scales. MDPI, 1-18. Pratiwi, D. N. (2017). Pengaruh Stakeholder Terhadap Carbon Emission Disclosure. Journal of Accounting and Finance, 2(1), 288-300.

Putri, A.W. (2016, Desember 16). Jawara SRA Award 2016. Retrieved on Maret 17, 2020 from https://swa.co.id/swa/csr-corner/jawara-sra-award-2016. 
Ramadhini, A., Adhariani, D., \& Djakman, C. D. (2020). The Effects of External Stakeholder Pressure on CSR Disclosure: Evidence from Indonesia. DLSU Business \& Economics Review, 29(2), 29-39.

Rudyanto, A. \& Siregar, S. V. (2018). The Effect of Stakeholder Pressure and Corporate Governance on the Quality of Sustainability Report. International Journal of Ethics and Systems, 5, 1-22.

Suharyani, R., Ulum, I., \& Jati, W. (2019). Pengaruh Tekanan Stakeholder dan

Corporate Governance Terhadap Kualitas Sustainability Report. Jurnal Akademi Akuntansi, 2(1), 71-92.

Susanto, Y. K. \& Joshua, D. (2018). Pengaruh Tata Kelola Perusahaan dan Karakteristik Perusahaan Terhadap Pengungkapan Tanggung Jawab Sosial Perusahaan. Ekuitas: Jurnal Ekonomi dan Keuangan, 2(4), 572-590.

Vitolla, F., Raimo, N., Rubino, M., \& Garzoni, A. (2019). How Pressure From Stakeholders Affects Integrated Reporting Quality. Corporate Social Responsibility and Environmental Management, 26(6), 1-16.

Weihena, K. N., Kawshala, B. A. H., \& Shamil, M. M. M. (2017). Relationship Between Stakeholder Power and Corporate Environmental Disclosures: Evidence from Listed Firms in Sri Lanka.

Yuliskayani, L. \& Damayanthi, I. G. A. E. (2018). Consumer Proximity, Media Exposure, Enviromental Sensitivity dan Profitability dalam Memengaruhi CSRD di Indonesia. E-Jurnal Akuntansi Universitas Udayana, 23(3), 16511681. 